\title{
Review
}

\section{Cannabinoids and the gastrointestinal tract}

\section{Summary}

The enteric nervous system of several species, including the mouse, rat, guinea pig and humans, contains cannabinoid $\mathrm{CB}_{1}$ receptors that depress gastrointestinal motility, mainly by inhibiting ongoing contractile transmitter release. Signs of this depressant effect are, in the whole organism, delayed gastric emptying and inhibition of the transit of non-absorbable markers through the small intestine and, in isolated strips of ileal tissue, inhibition of evoked acetylcholine release, peristalsis, and cholinergic and non-adrenergic non-cholinergic (NANC) contractions of longitudinal or circular smooth muscle. These are contractions evoked electrically or by agents that are thought to stimulate contractile transmitter release either in tissue taken from morphine pretreated animals (naloxone) or in unpretreated tissue ( $\gamma$-aminobutyric acid and 5-hydroxytryptamine). The inhibitory effects of cannabinoid receptor agonists on gastric emptying and intestinal transit are mediated to some extent by $\mathrm{CB}_{1}$ receptors in the brain as well as by enteric $\mathrm{CB}_{1}$ receptors. Gastric acid secretion is also inhibited in response to $\mathrm{CB}_{1}$ receptor activation, although the detailed underlying mechanism has yet to be elucidated. Cannabinoid receptor agonists delay gastric emptying in humans as well as in rodents and probably also inhibit human gastric acid secretion. Cannabinoid pretreatment induces tolerance to the inhibitory effects of cannabinoid receptor agonists on gastrointestinal motility. Findings that the $\mathrm{CB}_{1}$ selective antagonist/inverse agonist SR141716A produces in vivo and in vitro signs of increased motility of rodent small intestine probably reflect the presence in the enteric nervous system of a population of $\mathrm{CB}_{1}$ receptors that are precoupled to their effector mechanisms. SR141716A has been reported not to behave in this manner in the myenteric plexus-longitudinal muscle preparation (MPLM) of human ileum unless this has first been rendered cannabinoid tolerant. Nor has it been found to induce "withdrawal" contractions in cannabinoid tolerant guinea pig ileal MPLM. Further research is required to investigate the role both of endogenous cannabinoid receptor agonists and of non- $\mathrm{CB}_{1}$ cannabinoid receptors in the gastrointestinal tract. The extent to which the effects on gastrointestinal function of cannabinoid receptor agonists or antagonists/inverse agonists can be exploited therapeutically has yet to be investigated as has the extent to which these drugs can provoke unwanted effects in the gastrointestinal tract when used for other therapeutic purposes.

\section{The endocannabinoid system}

The plant Cannabis sativa is the source of a set of more than 60 oxygen containing aromatic hydrocarbon compounds called cannabinoids, of which $\Delta^{9}$-tetrahydrocannabinol $\left(\Delta^{9}\right.$-THC) is the main psychotropic constituent. Of the other plant cannabinoids, those which have been most investigated are $\Delta^{8}$-THC which has similar pharmacological properties to $\Delta^{9}$-THC, cannabinol, which has much weaker psychotropic properties than $\Delta^{9}$-THC, and cannabidiol, which lacks psychotropic activity. ${ }^{1}$ The effects of $\Delta^{9}$-THC are mediated primarily by cannabinoid receptors, at least two types of which are present in mammalian tissues. These are $C_{1}$ and $C_{2}$ receptors and both are members of the superfamily of $G$ protein coupled receptors. ${ }^{2} \mathrm{CB}_{1}$ receptors are found mainly on neurones in the brain, spinal cord, and peripheral nervous system, one of their functions being to modulate neurotransmitter release. The physiological roles of $\mathrm{CB}_{2}$ receptors, which are expressed mainly by immune cells, are proving more difficult to establish. Endogenous ligands for cannabinoid receptors have been identified, the most important being anandamide (arachidonylethanolamide) and 2-arachidonyl glycerol (2-AG). There is evidence that anandamide, and possibly also 2-AG, are removed from the extracellular space by a carrier mediated uptake process that is present in neurones and astrocytes. ${ }^{34}$ Once within the cell, anandamide is hydrolysed to arachidonic acid and ethanolamine by the enzyme fatty acid amide hydrolase (FAAH). ${ }^{3}$ This microsomal enzyme, which is found both in neurones and in some non-neuronal tissues, can also catalyse the hydrolysis of 2-AG. The "endocannabinoids", anandamide and $2-\mathrm{AG}$, and their receptors constitute the "endocannabinoid system".

As detailed elsewhere, ${ }^{56} \mathrm{a}$ wide range of ligands for $\mathrm{CB}_{1}$ and $\mathrm{CB}_{2}$ receptors have now been developed. Most notable among the $\mathrm{CB}_{1}$ selective ligands are the agonists $(R)-(+)-$ arachidonyl-1'-hydroxy-2'propylamide (methanandamide), arachidonyl-2'-chloroethylamide, and arachidonylcyclopropylamide, and the antagonists/inverse agonists SR141716A and LY320135. Of the $\mathrm{CB}_{1}$ selective agonists, methanandamide is less susceptible than anandamide to hydrolysis by FAAH. Important $\mathrm{CB}_{2}$ selective ligands include the agonists L759633, L759656, JWH-133, and HU-308, and the antagonist/inverse agonist SR144528. Inhibitors of endocannabinoid uptake and metabolism are also now available. ${ }^{5}{ }^{6}$ Among these are the anandamide uptake inhibitor $\mathrm{N}$-(4-hydroxyphenyl) arachidonylamide (AM404), and the potent FAAH inhibitors palmitylsulphonyl fluoride (AM374) and stearylsulphonyl fluoride (AM381). Many of the experiments described in this review have been performed with cannabinoid receptor agonists that have similar affinities for $\mathrm{CB}_{1}$ and $\mathrm{CB}_{2}$ receptors. Of these, the most commonly used have been WIN55212, which exhibits marginal $\mathrm{CB}_{2}$ selectivity, the "classical" cannabinoid $\Delta$ '-THC, and the "non-classical" cannabinoid CP55940.5 ${ }^{5}$ These agonists contain chiral centres and show marked stereoselectivity in both binding and functional assays. For classical and non-classical cannabinoids, those with the same absolute stereochemistry as $(-)-\Delta^{9}-$ THC at $6 \mathrm{a}$ and $10 \mathrm{a}(6 \mathrm{a} R, 10 \mathrm{a} R)$ have the greater activity (the (-)-enantiomers). However, for WIN55212, the $R-(+)$ enantiomer is the more active.

There is now good evidence for the presence of $\mathrm{CB}_{1}$ and $\mathrm{CB}_{2}$ receptors in the gastrointestinal tract. This article summarises this evidence and also considers what is currently known about the precise location of these receptors and the effects they mediate.

Abbreviations used in this paper: MPLM, myenteric plexuslongitudinal muscle preparation; $\Delta^{9}$-THC, $\Delta^{9}$-tetrahydrocannabinol; 2-AG, 2-arachidonyl glycerol; FAAH, fatty acid amide hydrolase; AM404, $N$-(4-hydroxyphenyl) arachidonylamide; L-NAME, $N^{\mathrm{G}}$-nitro-L-arginine methyl ester; AER, ascending enteric reflex; NANC, non-adrenergic non-cholinergic; PMSF, phenylmethylsulphonyl fluoride. 


\section{Cannabinoids inhibit electrically evoked} contractions of isolated small intestine

The ability of cannabinoids to inhibit electrically evoked contractions of isolated preparations of small intestine mounted in organ baths and the underlying mechanisms have been the subject of many investigations over the past 30 years. These have involved experiments, mainly with guinea pig tissue, in which contractions have been produced by electrical stimulation of prejunctional neurones rather than by direct stimulation of intestinal smooth muscle.

Among the first of these experiments were those described by Gill and colleagues. ${ }^{78}$ They investigated the response of the guinea pig isolated ileum to $\Delta^{9}$-THC or to various subfractions of petrol soluble and petrol insoluble fractions of tincture of cannabis BPC, then still a licensed medicine in the UK. The petrol insoluble fraction was found to contain material with atropine-like properties that opposed ileal contractions which had been evoked either by electrical stimulation or by acetylcholine. It also contained two substances with muscarinic properties that induced contractions of resting ileum. Two subfractions of the petrol soluble fraction also proved to have pharmacological activity. These were an ether eluate (fraction III) and one component of an ether/petroleum spirit eluate that contained $\Delta^{9}$-THC (fraction IIc). The effects of fraction III resembled the non-specific effect of alcohols: depression of both electrically evoked and acetylcholine evoked contractions. On the other hand, fraction IIc depressed the twitch response to electrical stimulation without affecting the response to added acetylcholine. This was most likely due to the $\Delta^{9}$-THC present in this subfraction as similar results were obtained with pure $\Delta^{9}$-THC. This effect of $\Delta^{9}$-THC has since been confirmed many times using isolated strips of whole ileum or of ileal longitudinal or circular muscle together with the neuronal networks that contain the final motor neurones that regulate the activity of smooth muscle. Experiments with such preparations have provided conclusive evidence that the small intestine contains $\mathrm{CB}_{1}$ receptors and that cannabinoid induced inhibition of electrically evoked contractions of small intestine is mediated by these receptors. This evidence is summarised below.

- Cannabinoid receptor agonists show high potency and remarkable stereoselectivity as inhibitors of electrically evoked contractions of isolated whole ileum or of MPLM of the ileum (table 1).

- As is to be expected for a receptor mediated response, the ability of particular cannabinoid receptor agonists to inhibit electrically evoked contractions of preparations of human or guinea pig ileum is concentration dependent and the relationship between log concentration and response is sigmoid in nature. ${ }^{9} 1012131718$

- The rank order of potencies of cannabinoids for inhibition of electrically evoked contractions of guinea pig MPLM or whole ileum correlates well with that of their psychotropic potencies and of their affinities for specific $\mathrm{CB}_{1}$ binding sites in brain tissue ${ }^{12-1419}$ (see also Pertwee $^{2}$ ).

- Using a quantitative autoradiographic binding technique, Lynn and Herkenham ${ }^{20}$ demonstrated that Peyer's patches from rat intestinal tract contain high affinity specific binding sites for $\left[{ }^{3} \mathrm{H}\right] \mathrm{CP} 55940$ and that the affinities of a selected range of cannabinoids for these binding sites correspond reasonably closely to their affinities for $\left[{ }^{3} \mathrm{H}\right] \mathrm{CP} 55940$ binding sites of rat brain. They also found $\left[{ }^{3} \mathrm{H}\right] \mathrm{CP} 55940$ to be more potently displaced from its Peyer's patch binding sites by $(-)-\Delta^{9}-$ THC or CP55940 than by the (+)-enantiomers of these cannabinoids or by cannabidiol, each of which has relatively low cannabinoid receptor affinity. Although Lynn and Herkenham ${ }^{20}$ were able to visualise $\left[{ }^{3} \mathrm{H}\right] \mathrm{CP} 55940$ binding sites in Peyer's patches located in rat jejunum, ileum, and rectum by autoradiography, they did not observe such binding sites elsewhere in these regions of the intestine or indeed in the rat stomach, duodenum, caecum, or colon. These negative findings may be an indication that cannabinoid receptors in the gastrointestinal tract are localised in discrete regions such as nerve terminals that form only a small part of the total tissue mass. Thus using the more sensitive technique of immunohistochemistry, it has been possible to visualise $\mathrm{CB}_{1}$ receptor immunoreactivity on neurones both in rat and guinea pig small intestine ${ }^{21}$ and in rat embryo digestive tract. ${ }^{22}$ In addition, saturation and displacement binding assays with membrane fractions obtained from guinea pig MPLM homogenates have revealed the presence of specific binding sites with properties similar to those of guinea pig brain $\mathrm{CB}_{1}$ receptors. ${ }^{23}$

- Polymerase chain reaction performed on cDNA prepared from RNA isolated from whole small intestine of guinea pig has revealed the presence in this tissue of both $\mathrm{CB}_{1}$ and $\mathrm{CB}_{2}$ or $\mathrm{CB}_{2}$-like RNA. ${ }^{24}$ However, $\mathrm{CB}_{1}$ but not $\mathrm{CB}_{2}$ or $\mathrm{CB}_{2}$-like mRNA was detected in guinea pig MPLM. $\mathrm{CB}_{1}$ mRNA has also been detected in human stomach and colon ${ }^{25}$ and all along the digestive tract of rat embryo. ${ }^{22}$

- Cannabinoid receptor agonist induced inhibition of electrically evoked contractions of guinea pig or human

Table 1 Stereoselective effects of cannabinoids on electrically evoked contractions of guinea pig isolated ileum or of the myenteric plexus-longitudinal muscle preparation (MPLM) of guinea pig ileum

\begin{tabular}{|c|c|c|c|c|}
\hline Procedure & Cannabinoid & Concentration & Effect on twitch amplitude & Ref \\
\hline Supramaximal stimulation of whole ileum at $0.1 \mathrm{~Hz}$ (ethanol) & $\begin{array}{l}(-)-\Delta^{8}-\mathrm{THC} \\
(+)-\Delta^{8}-\mathrm{THC} \\
(-)-11-\mathrm{OH}-\Delta^{9}-\mathrm{THC} \\
(+)-11-\mathrm{OH}-\Delta^{9}-\mathrm{THC}\end{array}$ & $\begin{array}{l}79.5 \mathrm{nM} \\
318 \mathrm{nM} \\
\text { ca. } 3 \mathrm{nM} \text { upwards } \\
61 \mathrm{nM}\end{array}$ & $\begin{array}{l}\text { Inhibition } \\
\text { None } \\
\text { Inhibition } \\
\text { None }\end{array}$ & 9 \\
\hline Stimulation of whole ileum at $0.1 \mathrm{~Hz}$ (ethanol) & $\begin{array}{l}(-)-\Delta^{9}-\mathrm{THC} \\
(+)-\Delta^{9}-\mathrm{THC}\end{array}$ & $\begin{array}{l}{ }^{\star} \mathrm{EC}_{50}=100 \mathrm{nM} \\
2 \mu \mathrm{M}\end{array}$ & $\begin{array}{l}\text { Inhibition } \\
\text { None }\end{array}$ & 10 \\
\hline Supramaximal stimulation of MPLM at $0.2 \mathrm{~Hz}$ (Cremophor EL) & $\begin{array}{l}(-)-\Delta^{9}-\mathrm{THC} \\
(+)-\Delta^{9}-\mathrm{THC}\end{array}$ & $\begin{array}{l}{ }^{\star} \mathrm{EC}_{50}=125 \mathrm{nM} \\
{ }^{\star} \mathrm{EC}_{50}=3.1 \mu \mathrm{M}\end{array}$ & $\begin{array}{l}\text { Inhibition } \\
\text { Inhibition }\end{array}$ & 11 \\
\hline Supramaximal stimulation of MPLM at $0.1 \mathrm{~Hz}$ (Tween 80 ) & $\begin{array}{l}\text { HU-210 } \\
\text { HU-211 }\end{array}$ & $\begin{array}{l}{ }^{\star} \mathrm{EC}_{50}=1.4 \mathrm{nM} \\
{ }^{\star} \mathrm{EC}_{50}>316 \mathrm{nM}\end{array}$ & $\begin{array}{l}\text { Inhibition } \\
\text { Inhibition }(316 \mathrm{nM})\end{array}$ & 12 \\
\hline Supramaximal stimulation of MPLM at $0.1 \mathrm{~Hz}$ (Tween 80 ) & $\begin{array}{l}\text { CP55940† } \\
\text { CP56667 }\end{array}$ & $\begin{aligned}{ }^{\star} \mathrm{EC}_{50} & =3.5 \mathrm{nM} \\
{ }^{\star} \mathrm{EC}_{50} & =162.9 \mathrm{nM}\end{aligned}$ & $\begin{array}{l}\text { Inhibition } \\
\text { Inhibition }\end{array}$ & 13 \\
\hline Supramaximal stimulation of MPLM at $0.1 \mathrm{~Hz}$ (Tween 80 ) & $\begin{array}{l}\text { (+)-WIN55212 } \\
\text { (-)-WIN55212 }\end{array}$ & $\begin{array}{l}\mathrm{EC}_{50}=5.5 \mathrm{nM} \\
1 \mu \mathrm{M}\end{array}$ & $\begin{array}{l}\text { Inhibition } \\
\text { Negligible }\end{array}$ & 1314 \\
\hline
\end{tabular}

${ }^{\star}$ Concentration producing $50 \%$ inhibition of the twitch response. Cannabinoid vehicle used is shown in paraentheses. †CP55940 has also been found to be more potent than CP56667 as a twitch inhibitor of mouse MPLM..$^{15}$

CP56667 is the (+)-enantiomer of CP55940 and HU-211 is the (+)-enantiomer of HU-210 (dimethylheptyl-11-hydroxy- $\Delta^{8}$-tetrahydrocannabinol).

The samples of $(+)-\Delta^{8}$-THC and $(+)-\Delta^{9}$-THC used probably contained $5-10 \%$ of the corresponding $(-)$-enantiomer. ${ }^{16}$ 
MPLM or of strips of circular smooth muscle of guinea pig ileum are prevented or reversed by SR141716A at concentrations well below $1 \mu \mathrm{M}$ but not by SR144528. ${ }^{13141826}$ Dissociation constant values obtained for SR141716A against (+)-WIN55212 or CP55940 correspond closely to the dissociation constant of SR141716A for displacement of $\left[{ }^{3} \mathrm{H}\right] \mathrm{CP} 55940$ from specific binding sites on guinea pig brain membranes ${ }^{23}$ or from human $\mathrm{CB}_{1}$ receptors. ${ }^{27}$

- $\mathrm{CB}_{1}$ receptors are negatively coupled through $\mathrm{G}_{\mathrm{i} / \mathrm{o}}$ proteins to adenylate cyclase and calcium channels. ${ }^{2}$ Consequently, the observations that (+)-WIN55212 induced inhibition of electrically evoked contractions of guinea pig MPLM can be enhanced by lowering the external calcium concentration and attenuated by elevating the external calcium concentration or by exposing the tissue to forskolin, 8-bromo-cAMP, or the phosphodiesterase inhibitor 3-isobutyl-1-methylxanthine, provide further evidence that this inhibitory effect is mediated by $\mathrm{CB}_{1}$ receptors. ${ }^{28}$

- Certain types of non-cannabinoid receptors can also mediate inhibition of electrically evoked twitches of guinea pig MPLM. As these include opioid and $\alpha_{2}$ adrenergic receptors, it is noteworthy that selective antagonists of one or other of these receptor types do not block or reverse the inhibitory effect of cannabinoid receptor agonists in this tissue. ${ }^{12-14}$ It has also been found that (+)-WIN55212 induced inhibition of electrically evoked contractions of circular smooth muscle of guinea pig ileum is unaffected by naloxone or by the nitric oxide synthase inhibitor, $N^{\mathrm{G}}$-nitro-L-arginine methyl ester $(\mathrm{L}-\mathrm{NAME}){ }^{26}$

\section{Enteric $\mathbf{C B}_{1}$ receptors mediate inhibition of evoked acetylcholine release}

Evidence that $\mathrm{CB}_{1}$ receptors mediate inhibition of electrically evoked contractions of small intestine or MPLM by decreasing evoked release of acetylcholine can be summarised as follows.

- Concentrations of a cannabis extract ("fraction IIc") or of $\Delta^{9}$-THC, 11-hydroxy- $\Delta^{8}$-THC, (+)-WIN55212, CP55940, or anandamide that inhibit electrically evoked contractions of guinea pig whole ileum or preparations of longitudinal (MPLM) or circular smooth muscle of guinea pig or human ileum have been found not to reduce the contractile response of these preparations to added acetylcholine,,$^{7-11} 13142629$ carbachol, ${ }^{18}$ substance P, or histamine, ${ }^{9629}$ each of which acts directly on smooth muscle. On the other hand, 11-hydroxy- $\Delta^{8}$-THC, $\Delta^{9}$-THC, and L-nantradol have been shown to reduce the contractile response of guinea pig whole ileum or MPLM to 5-hydroxytryptamine or $\gamma$-aminobutyric acid, drugs that act prejunctionally to increase acetylcholine release. ${ }^{910}{ }^{29-31}$ There is also a report that the ability of 11-hydroxy- $\Delta^{9}$-THC to inhibit electrically evoked contractions of strips of guinea pig ileum can be blocked by enhancing extracellular concentrations of acetylcholine by inhibiting acetylcholinesterase with physostigmine. ${ }^{9}$ It is noteworthy however that Layman and Milton ${ }^{32}$ found that submicromolar concentrations of $\Delta^{9}$-THC inhibited both electrically induced contractions of guinea pig ileum and contractions induced by administration of acetylcholine or histamine. These effects of $\Delta^{9}$-THC on acetylcholine and histamine induced contractions were probably non-specific in nature and unrelated to inhibition of the twitch response as cannabidiol was no less potent than $\Delta^{9}$-THC in inhibiting the responses to acetylcholine and histamine but did not inhibit the electrically evoked contractions.
- Experiments with guinea pig ileum or MPLM have shown $\Delta^{9}$-THC to decrease the output of acetylcholine from unstimulated tissues. ${ }^{32}{ }^{33}$ The effect of $\Delta^{9}$-THC was greatest when the initial spontaneous release of acetylcholine was high, suggesting that the cannabinoid was acting to reduce acetylcholine output to a basal level. ${ }^{33}$ This hypothesis is supported by the more recent finding that some concentrations of (+)-WIN55212 and CP55940 that inhibit electrically evoked contractions of guinea pig MPLM also inhibit electrically evoked acetylcholine release. ${ }^{13}{ }^{14}$ There is also a brief report that acetylcholine release from guinea pig MPLM evoked by electrical stimulation or by added resiniferatoxin or 5-hydroxytryptamine can be decreased by anandamide. ${ }^{34}$ Unexpectedly, although cannabidiol has generally been found not to inhibit electrically evoked contractions of guinea pig ileum, ${ }^{9} 102932$ there is one report that cannabidiol can reduce spontaneous acetylcholine output from strips of guinea pig ileum and that it elicits this response with greater potency than $\Delta^{9}$-THC. ${ }^{32}$

- As is to be expected for a $\mathrm{CB}_{1}$ receptor mediated response, the ability of (+)-WIN55212 and CP55940 to inhibit electrically evoked release of acetylcholine from guinea pig MPLM is not shared by (-)-WIN55212 and can be prevented or reversed by SR141716A. ${ }^{13}{ }^{14}$ The dissociation constant of SR141716A for antagonism of (+)-WIN55212 is not far removed from its dissociation constant for displacement of $\left[{ }^{3} \mathrm{H}\right] \mathrm{CP} 55940$ from guinea pig brain or human $\mathrm{CB}_{1}$ receptors. ${ }^{2327}$

\section{$\mathrm{CB}_{1}$ receptors in guinea pig MPLM are located prejunctionally}

There is good evidence that the $\mathrm{CB}_{1}$ receptors that apparently mediate inhibition of electrically evoked contractions of guinea pig MPLM are located prejunctionally on a subset of myenteric neurones of guinea pig small intestine that serve as the final motor neurones to longitudinal muscles. This is summarised below.

- The cannabinoid receptor agonists (+)-WIN55212 and CP55940 can potently reduce the amplitudes of evoked fast excitatory synaptic potentials of myenteric neurones of the $\mathrm{S}$ cell type, measured using conventional intracellular recording techniques. ${ }^{35}$ This inhibitory effect on cholinergic synaptic transmission was found to be dose related and stereoselective and to be reversed by SR141716A $(1 \mu \mathrm{M})$. Some $S$ neurones were insensitive to (+)-WIN55212, suggesting that not all such neurones bear cannabinoid receptors. (+)-WIN55212 also reduced the amplitude of slow (NANC) excitatory synaptic potentials of myenteric neurones of the $S$ cell type evoked by repetitive focal stimulation of interganglionic nerve fibres.

- Buckley and colleagues ${ }^{22}$ have reported the presence of $\mathrm{CB}_{1}$ mRNA in the myenteric and submucosal plexus of rat embryo digestive tract. In experiments with an affinity purified polyclonal antibody directed against the $\mathrm{N}$ terminal residues of the rat cloned $\mathrm{CB}_{1}$ receptor they also detected $\mathrm{CB}_{1}$ immunostaining at these sites. Using the same antibody to visualise the cellular distribution of $\mathrm{CB}_{1}$ receptors in adult guinea pig and rat MPLM by scanning confocal microscopy, Anavi-Goffer and colleagues ${ }^{21}$ have confirmed the presence of $\mathrm{CB}_{1}$ receptors on neurones of the myenteric plexus. Their results also support a close association of the $\mathrm{CB}_{1}$ receptors with cholinergic neurones of the myenteric plexus. In the guinea pig, punctate $\mathrm{CB}_{1}$ labelling was observed on fine nerve fibres within myenteric ganglia. $\mathrm{CB}_{1}$ positive fibres were seen to surround choline acetyltransferase containing ganglionic soma that were presumably the cell bodies of cholinergic neurones. $\mathrm{CB}_{1}$ receptor staining in 
guinea pig MPLM was also closely associated with glutamic acid decarboxylase containing fibres and hence presumably with GABAergic fibres. In rat MPLM, punctate labelling was observed within myenteric ganglia only on cell bodies. The $\mathrm{CB}_{1}$ receptor staining was associated with choline acetyltransferase containing ganglionic soma, indicating rat $\mathrm{CB}_{1}$ to be expressed by some cholinergic neurones. However, GABAergic fibres seemed to be completely dissociated from $\mathrm{CB}_{1}$ receptor labelling. In MPLM of both species, $\mathrm{CB}_{1}$ receptor staining was associated with synaptic labelling.

- Electrically evoked contractions of guinea pig and human MPLM that are susceptible to inhibition by cannabinoid receptor agonists can also be more or less completely abolished by $0.1,0.2$, or $1 \mu \mathrm{M}$ tetrodotoxin, a specific $\mathrm{Na}^{+}$channel blocker. ${ }^{18}{ }^{36}$ This finding implies that cannabinoids inhibit contractions caused by contractile transmitter release from neurones rather than by direct electrical stimulation of intestinal smooth muscle. It is therefore at least consistent with the hypothesis that cannabinoids inhibit electrically evoked contractions of MPLM by acting at prejunctional sites.

- The presence of $\mathrm{CB}_{1}$ receptors on intestinal prejunctional neurones is also supported by the evidence that $\mathrm{CB}_{1}$ receptors in the small intestine mediate inhibition of evoked neuronal release of acetylcholine (see above).

\section{Cannabinoid receptor agonists inhibit peristalsis in guinea pig isolated ileum}

Izzo and colleagues ${ }^{37}$ have recently demonstrated the effects of (+)-WIN55212 and CP55940 on peristalsis induced in segments of guinea pig isolated ileum by continuous intraluminal infusion of Krebs solution. These cannabinoids affected both the initial "preparatory phase" of peristalsis, in which the longitudinal muscle contracts in response to infusion of fluid, and the subsequent "emptying phase", in which the circular muscle contracts towards the aboral end of the intestine in a wave-like manner. More specifically, WIN55212 and CP55940 increased threshold pressure and volume for triggering peristalsis and decreased both longitudinal muscle reflex contraction occurring during the preparatory phase and resistance of the intestinal wall to the infused liquid (compliance), measured at the end of this phase. They also decreased maximal ejection pressure, measured during the emptying phase. All of these effects of (+)-WIN55212 and CP55940 were completely counteracted by $100 \mathrm{nM}$ SR141716A but not by $100 \mathrm{nM}$ SR144528, suggesting they were $\mathrm{CB}_{1}$ mediated.

Similarly, Heinemann and colleagues ${ }^{38}$ have reported that methanandamide can produce a concentration related inhibition of distension induced propulsive motility of luminally perfused strips of guinea pig isolated ileum. This effect could be attenuated by SR141716A $(1 \mu \mathrm{M})$, by the nitric oxide synthase inhibitor L-NAME, and by apamine, an inhibitor of small conductance calcium dependent potassium channels that in guinea pig small intestine are thought to mediate fast neuromuscular transmission from inhibitory motor neurones. However, it was not affected by naloxone or by the P2 ATP receptor antagonists suramin and pyridoxal-phosphate-6-azophenyl-2',4'-disulphonic acid. Heinemann and colleagues ${ }^{38}$ also found that ascending enteric reflex (AER) contraction of the circular muscle of the ileum induced by inflation of an intraluminal balloon could be inhibited by methanandamide, again in a SR141716A sensitive manner. Their results led Heinemann and colleagues ${ }^{38}$ to postulate that the effect of methanandamide on propulsive peristalsis of guinea pig isolated ileum is mediated by $\mathrm{CB}_{1}$ receptors which act (i) to activate inhibitory enteric motor pathways that oppose distension induced peristalsis by causing release of nitric oxide and apamine sensitive transmitters and (ii) to inhibit excitatory enteric motor pathways that mediate AER contraction of circular muscle in response to distension.

Heinemann and colleagues ${ }^{38}$ also found that under conditions in which peristalsis is thought to be maintained by endogenous tachykinins (blockade of cholinergic transmission with atropine or hexamethonium plus restoration of peristalsis with naloxone), the ability of methanandamide to inhibit propulsive peristalsis and AER contractions was not only preserved but enhanced. This finding prompted the proposal that, when activated, $\mathrm{CB}_{1}$ receptors of guinea pig ileum suppress propulsive peristalsis and AER contractions by inhibiting both cholinergic and non-cholinergic transmission. Evidence for this hypothesis has also been obtained by Izzo and colleagues ${ }^{26}$ in experiments with a circular muscle preparation. They found (+)-WIN55212 to inhibit cholinergic and NANC contractions evoked in this preparation by electrical stimulation and that both these inhibitory effects were potently antagonised by SR141716A. Similar results were obtained with anandamide. Interestingly, apamin reduced the inhibitory effect of (+)-WIN55212 on cholinergic contractions, pointing to cannabinoid induced activation of apamin sensitive inhibitory neurones. ${ }^{26}$ However, (+)-WIN55212 induced inhibition of NANC contractions was not modified by apamin. These NANC contractions were most likely produced by activation of postganglionic tachykinin $\mathrm{NK}_{1}$ and $\mathrm{NK}_{2}$ receptors as they were markedly attenuated by the combined administration of $\mathrm{NK}_{1}$ and $\mathrm{NK}_{2}$ antagonists but not by hexamethonium. ${ }^{26}$ On the other hand, (+)-WIN55212 induced inhibition of cholinergic and NANC contractions of circular muscle was most probably not mediated by nitric oxide or opioids as this inhibitory effect was not affected by L-NAME or naloxone. ${ }^{26}$

\section{Cannabinoids inhibit intestinal motility in the whole animal}

In line with the ability of cannabinoid receptor agonists to inhibit peristalsis and electrically evoked acetylcholine release and smooth muscle contractions in isolated segments of guinea pig ileum or MPLM are several reports that passage of an orally administered non-absorbable marker through the upper digestive tract can be inhibited by cannabinoids in rats ${ }^{39-41}$ and mice (table 2). Although cannabinoids delay gastric emptying (see below), their inhibitory effect on gastrointestinal transit seems to depend at least in part on cannabinoid induced reductions in intestinal motility as the effect has also been observed in rat experiments in which the transit marker was applied intraduodenally. ${ }^{39}$ As is to be expected from the in vitro data, the inhibitory effect of cannabinoids on intestinal transit seems to be $\mathrm{CB}_{1}$ receptor mediated. Thus the effect is produced in a dose related fashion by the established $\mathrm{CB}_{1} / \mathrm{CB}_{2}$ receptor agonists $\Delta^{8}$-THC, $\Delta^{9}-\mathrm{THC}$, nabilone, cannabinol, (+)-WIN55212, CP55940, and anandamide but not by the inactive (-)-enantiomer of WIN55212 or by cannabidiol $^{39} 40444^{47-51}$ and the effect of some $\mathrm{CB}_{1}$ agonists on intestinal transit has been found to be susceptible to antagonism by SR141716A but not by SR144528 $8^{40} 4148$ (see also table 2 ) or by naloxone. ${ }^{39} 40$

Other reported in vivo signs of cannabinoid induced inhibition of intestinal motility are a relaxant effect on the ileum of the anaesthetised cat observed in situ in response to two analogues of $\Delta^{6 \mathrm{a}, 10 \mathrm{a}}-\mathrm{THC},{ }^{52}$ a decrease in mouse faecal water content and in intraluminal fluid accumulation in rat small intestine induced by (+)-WIN55212, ${ }^{50}$ an inhibitory effect on faecal output, produced for example by $\Delta^{9}$-THC in rats ${ }^{53}{ }^{54}$ and by (+)-WIN55212 and anandamide in mice, ${ }^{50} 55$ and suppression by (+)-WIN55212 and cannabinol of croton oil induced diarrhoea as measured by 
Table 2 Effect of cannabinoids on transit of an orally administered non-absorbable marker through the small intestine of fasted mice

\begin{tabular}{|c|c|c|c|c|c|}
\hline Marker & Cannabinoid & Route and time of administration & Dose or potency & Effect on transit* & Ref \\
\hline Charcoal (30 min) & $\begin{array}{l}\Delta^{9}-\mathrm{THC} \\
\Delta^{8}-\mathrm{THC}\end{array}$ & sc immediately after marker & $\begin{array}{l}10 \text { or } 30 \mathrm{mg} / \mathrm{kg} \\
30 \mathrm{mg} / \mathrm{kg}\end{array}$ & $\begin{array}{l}-34 \% \\
-18 \%\end{array}$ & 4243 \\
\hline Charcoal (15 min) & $\begin{array}{l}\Delta^{9}-\mathrm{THC} \\
\mathrm{CBN}\end{array}$ & po at $45 \mathrm{~min}$ before marker & $\begin{array}{l}\mathrm{LED}=5 \mathrm{mg} / \mathrm{kg} \\
\mathrm{LED}=10 \mathrm{mg} / \mathrm{kg}\end{array}$ & $\begin{array}{l}-31.5 \% \\
-15.8 \%\end{array}$ & 44 \\
\hline Charcoal (15 min) & $\begin{array}{l}\Delta^{9} \text {-THC } \\
\Delta^{8}-\text { THC }\end{array}$ & po at $45 \mathrm{~min}$ before marker & $\begin{array}{l}\mathrm{ED}_{50}=20 \mathrm{mg} / \mathrm{kg} \\
\mathrm{ED}_{50}=13.5 \mathrm{mg} / \mathrm{kg}\end{array}$ & $\begin{array}{l}\text { Inhibition } \\
\text { Inhibition }\end{array}$ & 45 \\
\hline Charcoal (15 min) & $\Delta^{9}$-THC & po at $45 \mathrm{~min}$ before marker & $10 \mathrm{mg} / \mathrm{kg}$ & $-58 \%$ & 46 \\
\hline Charcoal (15 min) & $\Delta^{9}-\mathrm{THC}$ & po at $45 \mathrm{~min}$ before marker & $\mathrm{LED}=5 \mathrm{mg} / \mathrm{kg}$ & $-26 \%$ & 47 \\
\hline Radioactive marker & $\Delta^{9}-\mathrm{THC}$ & iv, po or icv & $\mathrm{ED}_{50}=1.3 \mathrm{mg} / \mathrm{kg}$ (iv) & Inhibition & 39 \\
\hline \multirow[t]{4}{*}{$(35 \mathrm{~min})$} & $\mathrm{CBN}$ & immediately before marker & $\mathrm{ED}_{50}=12 \mathrm{mg} / \mathrm{kg}$ (iv) & Inhibition & \\
\hline & Nabilone & & $\mathrm{ED}_{50}=1.6 \mathrm{mg} / \mathrm{kg}(\mathrm{po})$ & Inhibition & \\
\hline & $\Delta^{9}-\mathrm{THC}$ & & $\mathrm{ED}_{50}=31.6 \mu \mathrm{g} /$ mouse (iv) & Inhibition & \\
\hline & $\Delta^{9}-\mathrm{THC}$ & & $\mathrm{ED}_{50}=26.3 \mu \mathrm{g} /$ mouse (icv) & Inhibition & \\
\hline \multirow[t]{2}{*}{ Charcoal (20 min) } & AEA† & $\mathrm{sc}$ at $60 \mathrm{~min}$ before marker & $\mathrm{ED}_{50}=0.25 \mathrm{mg} / \mathrm{kg}$ & Inhibition & 48 \\
\hline & PEA & & $10 \mathrm{mg} / \mathrm{kg}$ & No effect & \\
\hline Carmine (20 min) & $(+)-W I N \dagger$ & ip at $20 \mathrm{~min}$ before marker & $\mathrm{LED}=0.25 \mathrm{mg} / \mathrm{kg}$ & ca. $-30 \%$ & 49 \\
\hline Charcoal (20 min) & $(+)-W I N \dagger$ & ip at $20 \mathrm{~min}$ before marker & $\mathrm{LED}=0.3 \mathrm{mg} / \mathrm{kg}$ & $-34 \%$ & 50 \\
\hline \multirow[t]{4}{*}{ Charcoal (20 min) } & (+)-WINt & ip at $20 \mathrm{~min}$ before marker & $\mathrm{ED}_{50}=169 \mathrm{nmol} / \mathrm{mouse}$ & Inhibition & 51 \\
\hline & $\mathrm{CBN}+$ & & $\mathrm{ED}_{50}=2760 \mathrm{nmol} / \mathrm{mouse}$ & Inhibition & \\
\hline & $(+)-W I N \dagger$ & $\mathrm{icv}$ at $20 \mathrm{~min}$ before marker & $\mathrm{ED}_{50}=104 \mathrm{nmol} / \mathrm{mouse}$ & Inhibition & \\
\hline & $\mathrm{CBN} \dagger$ & & $\mathrm{ED}_{50}=1829 \mathrm{nmol} / \mathrm{mouse}$ & Inhibition & \\
\hline \multirow[t]{3}{*}{ Charcoal $(20 \mathrm{~min}) \ddagger$} & (+)-WIN† & ip at $20 \mathrm{~min}$ before marker & $\mathrm{ED}_{50}=68 \mathrm{nmol} / \mathrm{mouse}$ & Inhibition & 51 \\
\hline & $\mathrm{CBN}+$ & & $\mathrm{ED}_{50}=1681 \mathrm{nmol} / \mathrm{mouse}$ & Inhibition & \\
\hline & $(+)-W I N$ & icv at $20 \mathrm{~min}$ before marker & $\mathrm{ED}_{50}=74 \mathrm{nmol} /$ mouse & Inhibition & \\
\hline
\end{tabular}

Time after administration of the non-absorbable marker at which the mice were killed is shown in paraentheses.

sc, subcutaneously; iv, intravenously; po, orally; icv, intracerebroventricularly.

LED, lowest effective dose investigated; AEA, anandamide; CBD, cannabidiol; CBN, cannabinol; PEA, palmitylethanolamide; WIN, WIN55212.

${ }^{\star}$ Compared with vehicle control.

†Antagonised by SR141716A at $1 \mathrm{mg} / \mathrm{kg} \mathrm{sc},{ }^{48} 0.62 \mathrm{mg} / \mathrm{kg}$ ip, ${ }^{49} 0.3 \mathrm{mg} / \mathrm{kg}$ ip, ${ }^{50}$ or $16 \mathrm{nmol} / \mathrm{mouse}$ ip. ${ }^{51}$

$\ddagger$ Experiments performed with mice exhibiting croton oil induced diarrhoea.

accelerated passage of charcoal through mouse small intestine $^{51}$ (see also table 2). The ability of (+)-WIN55212 to decrease mouse faecal water content and output, and the fluid volume of rat small intestine was opposed by SR141716A, supporting the involvement of $\mathrm{CB}_{1}$ receptors. $^{50}$ The inhibitory effects of (+)-WIN55212 and cannabinol on croton oil induced diarrhoea in mice were also antagonised by SR141716A but not by SR144528 ${ }^{51}$ (see also table 2).

In contrast with results they obtained with the opioid receptor agonist loperamide, Izzo and colleagues ${ }^{40}$ found that rat faecal output and water content were unaffected by (+)-WIN55212 or CP55940 at doses that inhibit upper intestinal transit. ${ }^{40}$ However, they found that onset of diarrhoea induced in rats by orally administered castor oil could be delayed by CP55940, although not by (+)-WIN55212. Thus the highest dose of CP55940 used in their experiments ( $1 \mathrm{mg} / \mathrm{kg}$ intraperitoneally) induced transient decreases both in the incidence of diarrhoea and in faecal water content. Neither of these effects was produced by (+)-WIN55212. It should be noted that the outcome measures used in the castor oil test presumably reflect the net activity of whole gut and that there is evidence that at least one cannabinoid ( $\Delta^{9}$-THC) has greater efficacy in inhibiting small intestinal transit than large bowel transit in rats. ${ }^{39}$ Whether the negative results obtained in some experiments with normal or castor oil treated rats are an indication that the inhibitory effect of cannabinoids on intestinal motility is exerted mainly on the small intestine will require further research as most cannabinoid experiments relating to intestinal motility have focused on this region of the gut.

As already discussed, SR144528 does not block cannabinoid induced inhibition of intestinal transit, making it unlikely that this effect is mediated by $\mathrm{CB}_{2}$ receptors. Even so, it would be premature to rule out the possibility that motility of some region of the gastrointestinal tract is modulated by this receptor type. This is because Hanus and colleagues ${ }^{56}$ have reported recently that the $\mathrm{CB}_{2}$ selective agonist $\mathrm{HU}-308$ has a marked inhibitory effect on the production of faecal pellets by mice and that this effect is readily attenuated by SR 144528 .

\section{Cannabinoids delay gastric emptying in the whole animal}

Shook and Burks ${ }^{39}$ found that intravenous administration of $\Delta^{9}$-THC inhibited the transit of a non-absorbable orally administered radioactive marker from mouse or rat stomach to small intestine, its potency in these two species being approximately the same. In mice, $\Delta^{9}$-THC was also active after intracerebroventricular injection. Other cannabinoids that have been reported to delay gastric emptying of an orally administered marker in rats or mice are WIN55212, CP55940, cannabinol, and nabilone. ${ }^{39} 4157$ There is also evidence that in rats, intravenous $\Delta^{9}$-THC can reduce both the contractile activity of stomach (and duodenum) and intragastric pressure. ${ }^{39}{ }^{58}$ It has been proposed by Krowicki and colleagues ${ }^{58}$ that $\Delta^{9}$-THC produces its inhibitory effects on the stomach partly by acting on the dorsal vagal complex of the hind brain to modulate vagal (parasympathetic) outflow to gastric smooth muscle. This hypothesis is based on their observations that the inhibitory effect of $\Delta^{9}$-THC on stomach motility and intragastric pressure can be abolished by bilateral vagotomy at the midcervical level and by hexamethonium but not by transection of the cervical spinal cord.$^{58} \Delta^{9}$-THC may also alter gastric motility by acting directly on the vagus nerves and on the gastrointestinal myenteric plexus. ${ }^{58}$

It is likely that cannabinoids alter gastric motility by acting through $\mathrm{CB}_{1}$ receptors. Thus the inhibitory effects of (+)-WIN55212, CP55940, and cannabinol on gastric emptying in rats and of $\Delta^{9}$-THC on rat gastric contractile activity and intragastric pressure can be prevented by SR141716A. ${ }^{41}{ }^{57}{ }^{58}$ Moreover, SR144528 does not antagonise (+)-WIN55212 or cannabinol induced inhibition of gastric emptying in rats. ${ }^{57}$ It has also been found that the effect of $\Delta^{9}$-THC in mice on gastric emptying (and small bowel transit) is not blocked by naloxone. ${ }^{39} \mathrm{By}$ themselves neither SR141716A nor SR144528 significantly affected gastric emptying in rats. ${ }^{57}$ However, SR141716A was unexpectedly found to share the ability of $\Delta^{9}$-THC to reduce rat intragastric pressure. ${ }^{58}$

In agreement with animal data, McCallum and colleagues $^{59}$ have found $\Delta^{9}$-THC to delay gastric emptying in 
human subjects fasted for eight hours when this was monitored for two hours after ingestion of a radiolabelled solid test meal and $\Delta^{9}$-THC $\left(10 \mathrm{mg} / \mathrm{m}^{2}\right)$ or placebo was administered one hour before the meal. The trial was randomised and double blind, and was performed with nine male and four female experienced cannabis users. In contrast, Bate$\operatorname{man}^{60}$ found that gastric emptying, monitored by a real time ultrasound technique, was unaffected by $\Delta^{9}$-THC in seven fasted cannabis naive male volunteers that had consumed $500 \mathrm{ml}$ of warm orange cordial 30 minutes after injection. The doses of $\Delta^{9}$-THC used in this study ( 0.5 and $1 \mathrm{mg}$ intravenously) increased pulse rate and produced cannabis-like psychomotor and psychological effects.

\section{Cannabinoids inhibit gastric acid secretion}

Coruzzi and colleagues ${ }^{61}$ found that (+)-WIN55212 (0.5-2 $\mathrm{mg} / \mathrm{kg}$ intravenously) markedly inhibited pentagastrin stimulated gastric acid secretion in urethane anaesthetised rats without affecting basal secretion. It is likely that this effect was mediated by $\mathrm{CB}_{1}$ receptors. Thus no such effect was observed in response to (-)-WIN55212 or to the $\mathrm{CB}_{2}$ selective agonist JWH-015, and (+)-WIN55212 was antagonised by SR141716A and LY320135 but not by SR144528. By themselves, neither SR141716A nor LY320135 affected either basal or pentagastrin stimulated gastric acid secretion. There has also been a report that in a rat isolated stomach preparation, histamine induced but not basal gastric acid secretion is inhibited by $\Delta^{9}$-THC at the rather high concentration of $20 \mu \mathrm{M} .^{62}$ This effect was essentially abolished by cyclic AMP but was unaffected by propranolol. In view of these findings it is noteworthy that Nalin and colleagues ${ }^{63}$ found a link between the self reported heavy smoking of cannabis by 90 human subjects (more than two days per week) and low gastric acid output. Gastric acid production was measured at least one day after admission into a quarantined study ward in which cannabis (or alcohol) consumption was not allowed. Interestingly, it was also found in this investigation that ingestion of bacterial pathogens precipitated more voluminous diarrhoea in heavy users of cannabis than in light users. Possibly this was because the lower acid content of the stomachs of the heavy users allowed more of the ingested pathogens to survive gastric transit. ${ }^{63}$ Another consequence of the inhibitory effect of cannabinoids on gastric acid secretion could be the prevention of gastric ulcer formation. Indeed, gastric ulcer formation in fasted rats measured six hours after ligation of the pylorus (Shay rat test) was found to be markedly reduced by $\Delta^{9}$-THC $(100 \mathrm{mg} / \mathrm{kg}$ subcutaneously or orally) when this was administered 30 minutes before ligation. ${ }^{64}$

\section{The endocannabinoid system of the digestive tract is tonically active}

ISOLATED GUINEA PIG ILEUM

When administered by itself at concentrations of $10 \mathrm{nM}$ or above, SR141716A has been found to increase the amplitude of both electrically evoked contractions of guinea pig MPLM and cholinergic and NANC contractions elicited by electrical field stimulation of a circular smooth muscle preparation of guinea pig ileum. ${ }^{131426} 65$ That SR141716A was acting as a cholinesterase inhibitor in these tissue preparations is unlikely as it did not potentiate contractions produced by added acetylcholine. SR141716A has also been reported to augment electrically evoked acetylcholine release from guinea pig MPLM (in the presence of physostigmine $)^{14}$ and to increase both distension induced ascending enteric reflex contraction of segments of ileal circular muscle ${ }^{38}$ and maximal ejection pressure in isolated strips of guinea pig whole ileum exhibiting peristalsis in response to continuous intraluminal infusion of Krebs solution. ${ }^{37}$ These effects of SR141716A on acetylcholine release, evoked contractions and peristalsis, are opposite in direction to those produced in the same assay systems by cannabinoid receptor agonists.

One possible explanation for the production of such "inverse cannabimimetic effects" is that these intestinal preparations are releasing endocannabinoid(s) onto cannabinoid receptors and that SR141716A is reducing the resulting background tone by occupying these receptors. Another possible explanation springs from evidence that SR141716A is an inverse agonist rather than a "pure" or "silent" antagonist (see Pertwee ${ }^{5}$ ). According to this explanation it is assumed that cannabinoid receptors can exist in a "precoupled" state and that inverse agonists can reduce the extent of this precoupling. Consistent with the first of these hypotheses is evidence that the guinea pig ileum contains the anandamide and 2-AG metabolising enzyme FAAH, and also a mechanism for endocannabinoid uptake. Thus the presence of FAAH has been demonstrated in rat intestine ${ }^{66-68}$ and there are reports that certain effects of anandamide on guinea pig MPLM can be potentiated by the anandamide uptake inhibitor AM404, and by a general protease inhibitor phenylmethylsulphonyl fluoride (PMSF) that is known to inhibit FAAH. More specifically, experiments with guinea pig MPLM have shown PMSF to potentiate anandamide induced inhibition of electrically evoked contractions ${ }^{17}$ and AM404 to potentiate anandamide induced inhibition of resiniferatoxin evoked acetylcholine release. ${ }^{34}$ However, these data should be interpreted with caution as there is now evidence that AM404 shares the ability of resiniferatoxin to activate vanilloid receptors. ${ }^{69}{ }^{70}$ It is also noteworthy that the endocannabinoid 2-AG was first isolated from canine small intestine. ${ }^{71}$

While there is evidence for the presence in guinea pig ileum of anandamide uptake and metabolising mechanisms, there is none that anandamide is released when this tissue is electrically stimulated. Thus not all ligands capable of antagonising $\mathrm{CB}_{1}$ mediated inhibition of electrically evoked contractions of guinea pig MPLM share the ability of SR141716A to enhance such contractions when administered alone $e^{23} 6572$ and, when added by itself, PMSF does not mimic the inhibitory effect of anandamide on electrically evoked contractions of guinea pig MPLM. ${ }^{17}$ Moreover, while the endocannabinoid 2-AG has been detected in the small intestine of dog, there is no evidence for the presence of anandamide in the digestive tract. ${ }^{71}$ It seems likely therefore that the ability of SR141716A to produce inverse cannabimimetic effects in guinea pig ileum depends primarily on the putative inverse agonist properties of this ligand and reflects the presence in this tissue of $\mathrm{CB}_{1}$ receptors in a precoupled state.

Although SR141716A enhances electrically evoked contractions of guinea pig MPLM, no such effect has been observed in human MPLM. ${ }^{18}$ Nor has SR141716A been found to produce effects opposite in direction to those of cannabinoid receptor agonists on threshold pressure or volume for triggering peristalsis or on longitudinal muscle reflex contraction, intestinal wall compliance, or propulsive motility measured during peristalsis in segments of guinea pig isolated ileum. ${ }^{37} 38$

INTESTINAL MOTILITY IN THE WHOLE ANIMAL

Administration of SR141716A by itself, sometimes at doses slightly higher than those sufficient to antagonise cannabinoid receptor agonists, has been found to stimulate propulsion of non-absorbable markers through $\mathrm{rat}^{40}$ or mouse intestine (table 3). That this is a reflection of the inverse agonist properties of SR141716A rather than of ongoing release of an endogenous cannabinoid receptor 
Table 3 Effect of SR141716A on transit of an orally administered non-absorbable marker through the small intestine of fasted mice

\begin{tabular}{|c|c|c|c|c|}
\hline Marker & $\begin{array}{l}\text { Route and time of } \\
\text { administration }\end{array}$ & Dose or potency & $\begin{array}{l}\text { Effect on } \\
\text { transit * }\end{array}$ & Ref \\
\hline Charcoal (20 min) & sc before marker & $1 \mathrm{mg} / \mathrm{kg}$ & $+17.5 \%$ & 48 \\
\hline Carmine $(20 \mathrm{~min})$ & $\begin{array}{l}\text { ip at } 20 \mathrm{~min} \\
\text { before marker }\end{array}$ & $\mathrm{LED}=1.25 \mathrm{mg} / \mathrm{kg}$ & $\begin{array}{l}\text { ca. } \\
+33 \%\end{array}$ & 49 \\
\hline Charcoal (20 min) & $\begin{array}{l}\text { ip at } 20 \text { min } \\
\text { before marker }\end{array}$ & $\mathrm{LED}=1 \mathrm{mg} / \mathrm{kg}$ & $+48 \%$ & 50 \\
\hline Charcoal (20 min) & $\begin{array}{l}\text { ip at } 20 \text { min } \\
\text { before marker } \\
\text { icv at } 20 \text { min } \\
\text { before marker }\end{array}$ & $\begin{array}{l}\mathrm{ED}_{50}=375 \\
\mathrm{nmol} / \text { mouse } \\
\mathrm{ED}_{50}=117 \\
\mathrm{nmol} / \text { mouse }\end{array}$ & $\begin{array}{l}\text { Increase } \\
\text { Increase }\end{array}$ & 51 \\
\hline $\begin{array}{l}\text { Charcoal }(20 \mathrm{~min}) \\
\quad \text { (croton oil treated mice) }\end{array}$ & $\begin{array}{l}\text { ip at } 20 \text { min } \\
\text { before marker }\end{array}$ & $\begin{array}{l}\mathrm{ED}_{50}=418 \\
\mathrm{nmol} / \mathrm{mouse}\end{array}$ & Increase & 51 \\
\hline
\end{tabular}

Time after administration of the non-absorbable marker at which the mice were killed is shown in parentheses.

${ }^{\star}$ Compared with vehicle control.

LED, lowest effective dose investigated.

agonist is suggested by data obtained in vitro (see above) and also by the observation that the anandamide uptake inhibitor AM404 does not affect passage of a charcoal meal along mouse intestine when administered alone or potentiate the inhibitory effect on charcoal meal transit of exogenously administered anandamide. ${ }^{48}$ It should be borne in mind however that AM404 is not only an anandamide uptake inhibitor but also a vanilloid receptor agonist and may therefore induce acetylcholine release from the small intestine (see above).

SR141716A has also been found to increase charcoal transit through the small intestine of mice exhibiting diarrhoea induced by croton oil, albeit to no greater an extent than in croton oil free mice ${ }^{51}$ (see also table 3 ). In addition, it has been shown to stimulate rat or mouse defecation in some $\mathrm{e}^{4050}{ }^{73}$ but not all experiments ${ }^{55}$ and to increase mouse faecal water content and the fluid content of rat small intestine..$^{5073}$ No effect on intestinal transit has been observed in response to SR $144528 .^{40} 51$

\section{Central sites of action}

There is some evidence that cannabinoid receptor agonists and SR141716A can affect gastrointestinal motility by interacting with sites in the brain. More specifically, there are reports that rat and mouse gastric emptying and intestinal transit can be altered by intracerebroventricular administration of $\Delta^{9}$-THC, cannabinol, (+)-WIN55212, or SR141716A and that the changes in intestinal transit so produced can be abolished by intraperitoneal hexamethonium. ${ }^{39}{ }^{41}{ }^{51}$ However, these central sites probably contribute relatively little to the effects of peripherally administered cannabinoids as it has been found that intracerebroventricular treatment with SR141716A antagonising the inhibitory effects on gastric and intestinal transit of intracerebroventricular (+)-WIN55212 produces no such antagonism when these inhibitory effects are provoked by intraperitoneal administration of (+)-WIN55212. ${ }^{41}$ Further evidence for the relatively greater importance of peripheral sites of action comes from experiments showing that the ability of intraperitoneal SR141716A to increase mouse intestinal transit and the fluid content of rat small intestine can be attenuated or abolished by atropine but not by hexamethonium or by combined administration of $\mathrm{NK}_{1}$ and $\mathrm{NK}_{2}$ antagonists. ${ }^{50}$ These findings point to the involvement of a tachykinin independent mechanism that relies on activation of peripheral muscarinic cholinoceptors. ${ }^{50}$ It is also likely that (+)-WIN55212 or cannabinol inhibit croton oil induced diarrhoea by acting peripherally, as this inhibition is also not blocked by hexamethonium. ${ }^{51}$

Gastrointestinal signs of tolerance and dependence There are several reports that in vivo or in vitro pretreatment with cannabinoids can produce tolerance to the inhibitory effects of these drugs on gastrointestinal activity. More specifically, Anderson and colleagues ${ }^{46}$ found that mice pretreated with $\Delta^{9}$-THC $10 \mathrm{mg} / \mathrm{kg}$ orally once daily for 2-4 days developed tolerance to the inhibitory effect of this cannabinoid on the gastrointestinal passage of a charcoal meal. Some degree of tolerance to a challenging injection of $\Delta^{9}$-THC was still detectable even after 19 drug free days. Pertwee and colleagues ${ }^{74}$ pretreated mice with $\Delta^{9}$-THC $20 \mathrm{mg} / \mathrm{kg}$ subcutaneously once daily for three days, or with its vehicle Tween 80 . They found that the inhibitory effect of $100 \mathrm{nM}$ CP55940 on electrically evoked contractions of segments of MPLM was less in tissue that had been obtained from $\Delta^{9}$-THC pretreated mice 24-28 hours after the final injection than in tissue obtained from vehicle pretreated animals. Similar results were found in guinea pigs pretreated with $\Delta^{9}$-THC $10 \mathrm{mg} / \mathrm{kg}$ intraperitoneally once daily for two days, or with its vehicle Tween $80 .^{75}$ In these experiments, $\Delta^{9}$-THC pretreatment was found to produce significant dextral shifts in the log concentration-response curves of $\Delta^{9}$-THC and CP55940 for inhibition of electrically evoked contractions of MPLM, without inducing tolerance to the contractile effect of acetylcholine. It also decreased the size of the maximal responses to $\Delta^{9}$-THC and CP55940, a possible indicator of a reduction in cannabinoid receptor density and/or coupling efficiency. Basilico and colleagues ${ }^{76}$ exposed segments of guinea pig MPLM for five hours to a concentration of (+)-WIN55212 (50 nM) expected to reduce the amplitude of electrically evoked contractions by $50 \%$. At the end of this period, the amplitude of evoked contractions was no less in the (+)-WIN55212 treated tissues than in untreated tissues, indicating the development of tolerance. Guagnini and colleagues ${ }^{77}$ preincubated MPLM of human ileum or distal jejunum at $18^{\circ} \mathrm{C}$ for 48 hours with $10 \mu \mathrm{M}(+)$ - or (-)-WIN55212. Preincubation with the (+)-enantiomer but not with (-)-WIN55212 completely abolished the inhibitory effect of (+)-WIN55212 on electrically evoked contractions of MPLM. They also found that twitch responses were markedly enhanced by $1 \mu \mathrm{M}$ SR141716A in tissues that had been preincubated with (+)-WIN55212 but not in tissues that had been preincubated with (-)-WIN55212 or with the drug vehicle DMSO (SR141716A does not induce inverse cannabimimetic effects in human MPLM). ${ }^{18}$ Accordingly, this preparation may serve as an in vitro model for cannabinoid dependence. In line with the observation of Guagnini and colleagues ${ }^{77}$ is a finding by Lichtman and colleagues ${ }^{78}$ that one of the withdrawal signs induced by SR141716A in $\Delta^{9}$-THC tolerant dogs is diarrhoea. It is noteworthy however that SR141716A $(1 \mu \mathrm{M})$ has been reported not to induce "withdrawal" contractions in resting (+)-WIN55212 tolerant guinea pig MPLM. ${ }^{76}$

In their experiments with guinea pig MPLM, Basilico and colleagues ${ }^{76}$ also obtained evidence for the development of cross tolerance between (+)-WIN55212 and morphine. They observed significant dextral shifts in the log concentration-response curve for inhibition of electrically evoked contractions of both (+)-WIN55212 and morphine in MPLM that had been preincubated for five hours with either of these agonists. In contrast, tolerance to the inhibitory effect of normorphine (or clonidine) on electrically evoked contractions was not detected by Pertwee and colleagues $^{75}$ in guinea pig MPLM that had been rendered cannabinoid tolerant by in vivo pretreatment with $\Delta^{9}$-THC.

Finally, there is evidence that cannabinoid receptor agonists can suppress increases in gastrointestinal activity precipitated by naloxone in morphine dependent animals. Hine and colleagues ${ }^{79}$ found that $\Delta^{9}$-THC but not cannabidiol produced a dose related blockade of naloxone 
induced signs of heightened gastrointestinal activity (diarrhoea and increased defecation) as well as other abstinence signs in morphine dependent rats. These findings led them to conclude that cannabinoids might have potential for the management of opioid withdrawal in the clinic. Frederickson and colleagues ${ }^{80}$ found that "withdrawal" contractions induced by naloxone in ileum taken from guinea pigs that had been treated with a slow release morphine suspension could be attenuated by $(-)$ - but not by $(+)-\Delta^{9}-$ THC at a concentration $(95 \mathrm{nM})$ that did not affect contractions produced by acetylcholine. Morrone and colleagues ${ }^{81}$ reported that a cannabis extract $\left(5.2 \mu \mathrm{M} \Delta^{9}-\mathrm{THC}\right)$ reduced naloxone induced "withdrawal" contractions in segments of guinea pig ileum and rabbit jejunum that had been preincubated for five minutes with morphine or with the $\kappa$ opioid receptor agonist U-50,488H. Acetylcholine induced contractions were not blocked by the cannabis. Basilico and colleagues" found that "withdrawal" contractions induced by naloxone in strips of guinea pig MPLM that had been rendered opioid and cannabinoid tolerant by a five hour exposure to morphine could be prevented by $50 \mathrm{nM}(+)$-WIN55212. Because $\mathrm{CB}_{1}$ receptors can mediate suppression of acetylcholine release in the myenteric plexus (see above) and because naloxone precipitated "withdrawal" contractions of MPLM are thought to be triggered by the endogenous release of acetylcholine, 5-HT, and substance $P$ into neuromuscular synapses, it is possible that (+)-WIN55212 attenuates these contractions by inhibiting the release of one or more of these contractile agents $^{7680}$ (see also above). Another possibility is that (+)-WIN55212 interacts directly with $\mu$ opioid receptors. ${ }^{76}$

\section{Conclusions}

There is little doubt from the animal data described in this review that the endocannabinoid system extends into the enteric nervous system where it exerts an inhibitory influence on the processes of gastric emptying and peristalsis. These effects on gastrointestinal motility seem to be largely mediated by peripheral $\mathrm{CB}_{1}$ receptors that inhibit ongoing contractile transmitter release when activated. Gastric acid secretion can also be inhibited in response to $\mathrm{CB}_{1}$ receptor activation although the underlying mechanisms have yet to be elucidated in detail. Cannabinoid pretreatment induces tolerance to the inhibitory effects of cannabinoid receptor agonists on gastrointestinal motility. However, the ability of naloxone to induce "withdrawal" contractions in opioid pretreated intestinal tissue seems not to be shared by the $\mathrm{CB}_{1}$ selective antagonist SR141716A when this is added to intestinal tissue that has been rendered cannabinoid tolerant by in vitro pretreatment with the cannabinoid receptor agonist (+)-WIN55212. Non-CB 1 receptors for cannabinoids that are present in the gastrointestinal tract include (i) $\mathrm{CB}_{2}$ or $\mathrm{CB}_{2}$-like receptors and (ii) vanilloid VR1 receptors that can be activated by anandamide and some of its analogues but not by non-eicosanoid cannabinoids. However, the part played by vanilloid VR1 receptors in the pharmacology of exogenously administered or endogenously released anandamide and the role(s) of gastrointestinal $\mathrm{CB}_{2}$ or $\mathrm{CB}_{2}$-like receptors in health or disease remain to be established.

The observation that inverse cannabimimetic effects can be produced by the $\mathrm{CB}_{1}$ receptor inverse agonist SR141716A in mouse, rat, or guinea pig intestine constitutes evidence that the endocannabinoid system is tonically active in the intestinal tract. This tonic activity seems to arise from the presence of a population of $\mathrm{CB}_{1}$ receptors that are precoupled to their effector mechanisms rather than from the endogenous release of endocannabinoids. Evidence for the presence of precoupled $\mathrm{CB}_{1}$ receptors in the human intestine has also been obtained, albeit only in tissue (ileum) that has been rendered cannabinoid tolerant by prior exposure to a cannabinoid receptor agonist. Further experiments are now required to determine whether there are any disease states in which $\mathrm{CB}_{1}$ receptor precoupling is increased and also whether endogenously released endocannabinoids ever contribute to the control of gastrointestinal function.

Cannabinoid receptor agonists delay gastric emptying in humans as well as in rodents, and they may also inhibit human gastric acid secretion. It is also worth noting that there have been a number of anecdotal accounts of the effective use of cannabis in the past against dysentery and cholera. ${ }^{82}$ Even so, the extent to which the inhibitory effects of cannabinoid receptor agonists or antagonists/inverse agonists on gastrointestinal motility and/or on gastric acid secretion can be exploited in the present day clinic has yet to be investigated in depth. So too has the extent to which these drugs provoke unwanted effects in the gastrointestinal tract when used for other medicinal purposes. The therapeutic implications of the existence of a group of drugs, the cannabinoids, that possesses anti-inflammatory and analgesic properties ${ }^{83}$ coupled to an inhibitory effect on gastric acid secretion also warrants investigation. Clearly there is now a need both for clinical studies and for a more detailed elucidation through non-clinical research of the role of the endocannabinoid system in the gastrointestinal tract.

R G PERTWEE Department of Biomedical Sciences, Institute of Medical Sciences, University of Aberdeen Foresterhill, Aberdeen AB25 2ZD, UK rgp@aberdeen.ac.uk

Some of the research described in this article was supported by grants from the National Institute on Drug Abuse (DA 09158 and DA 09789) and from the Wellcome Trust.

1 Pertwee RG. The central neuropharmacology of psychotropic cannabinoids. Pharmacol Ther 1988;36:189-261.

2 Pertwee RG. Pharmacology of cannabinoid $\mathrm{CB}_{1}$ and $\mathrm{CB}_{2}$ receptors. Pharmacol Ther 1997;74:129-80.

3 Di Marzo V, Melck D, Bisogno T, et al. Endocannabinoids: endogenous cannabinoid receptor ligands with neuromodulatory action. Trends Neurosci 1998;21:521-8.

4 Piomelli D, Beltramo M, Glasnapp S, et al. Structural determinants for recognition and translocation by the anandamide transporter. Proc Natl Acad Sci USA 1999;96:5802-7.

5 Pertwee RG. Pharmacology of cannabinoid receptor ligands. Curr Med Chem 1999;6:635-64

6 Pertwee RG. Cannabinoid receptor ligands: clinical and neuropharmacological considerations relevant to future drug discovery and development. Exp Opin Invest Drugs 2000;9:1553-71.

7 Gill EW, Paton WDM, Pertwee RG. Preliminary experiments in the chemistry and pharmacology of cannabis. Nature 1970;228:134-6.

8 Gill EW, Paton WDM. Pharmacological experiments in vitro on the active principles of cannabis. In: Joyce CRB, Curry SH, eds. The botany and chemistry of cannabis. London: Churchill, 1970:165-73.

9 Rosell S, Agurell S, Martin B. Effects of cannabinoids on isolated smooth muscle preparations. In: Nahas GG, ed. Marihuana: chemistry, biochemistry, and cellular effects. New York: Springer-Verlag, 1976:397-406.

10 Nye JS, Seltzman HH, Pitt CG, et al. High affinity cannabinoid binding sites in brain membranes labeled with $\left[{ }^{3} \mathrm{H}\right]-5^{\prime}$-trimethylammonium $\Delta^{8}$ tetrahydrocannabinol. F Pharmacol Exp Ther 1985;234:784-91.

11 Roth SH. Stereospecific presynaptic inhibitory effect of $\Delta^{9}$ tetrahydrocannabinol on cholinergic transmission in the myenteric plexus tetrahydrocannabinol on cholinergic transmission in the my
of the guinea pig. Can $\mathcal{F}$ Physiol Pharmacol 1978;56:968-75.

12 Pertwee RG, Stevenson LA, Elrick DB, et al. Inhibitory effects of certain enantiomeric cannabinoids in the mouse vas deferens and the myenteric plexus preparation of guinea pig small intestine. Br f Pharmacol 1992;105: plexus p
$980-4$.

13 Pertwee RG, Fernando SR, Nash JE, et al. Further evidence for the presence of cannabinoid $\mathrm{CB}_{1}$ receptors in guinea pig small intestine. Br F Pharmacol 1996;118:2199-205

14 Coutts AA, Pertwee RG. Inhibition by cannabinoid receptor agonists of acetylcholine release from the guinea pig myenteric plexus. Br f Pharmacol 1997;121:1557-66.

15 Pertwee RG, Stevenson LA, Fernando SR, et al. In vitro effects of the cannabinoid, CP55,940, and of its (+)-enantiomer, CP56,667. In: Harris L, ed. Proceeding of the 54th annual scientific meeting of the college on problems of drug dependence. Rockville, Maryland: National Institute on Drug Abuse, 1993:132;374.

16 Mechoulam R, Devane WA, Glaser R. Cannabinoid geometry and biological activity. In: Murphy L, Bartke A, eds. Marijuana/cannabinoids neurobiolcal activity. In: Murphy L, Bartke A, eds. Marijuana/cannabinoids
ogy and neurophysiology. Boca Raton: CRC Press Inc., 1992:1-33.

17 Pertwee RG, Fernando SR, Griffin G, et al. Effect of phenylmethylsulphonyl fluoride on the potency of anandamide as an inhibitor of electrically evoked contractions in two isolated tissue preparations. Eur F Pharmacol 1995;272: 73-8. 
18 Croci T, Manara L, Aureggi G, et al. In vitro functional evidence of neuronal cannabinoid $\mathrm{CB}_{1}$ receptors in human ileum. Br f Pharmacol 1998;125: nal canna $1393-5$.

19 Rosell S, Björkroth U, Agurell S, et al. Relation between effects of cannabinoid derivatives on the twitch response of the isolated guinea pig ileum and their psychotropic properties. In: Nahas GG, Paton WDM, eds. Marihuana: biological effects. Oxford: Pergamon Press, 1979:63-70.

20 Lynn AB, Herkenham M. Localization of cannabinoid receptors and nonsaturable high-density cannabinoid binding sites in peripheral tissues of the rat: implications for receptor-mediated immune modulation by cannabinoids. F Pharmacol Exp Ther 1994;268:1612-23.

21 Anavi-Goffer S, Irving A, Pertwee R, et al. The cellular distribution of $\mathrm{CB}_{1}$ receptors in the myenteric plexus. International Cannabinoid Research So

22 Buckley NE, Hansson S, Harta G, et al. Expression of the $\mathrm{CB}_{1}$ and $\mathrm{CB}_{2}$ receptor messenger RNAs during embryonic development in the rat. Neuroscience 1998;82:1131-49.

23 Ross RA, Brockie HC, Fernando SR, et al. Comparison of cannabinoid binding sites in guinea pig forebrain and small intestine. Br f Pharmacol 1998;125:1345-51.

24 Griffin G, Fernando SR, Ross RA, et al. Evidence for the presence of $\mathrm{CB}_{2}$ like cannabinoid receptors on peripheral nerve terminals. Eur $\mathcal{F}$ Pharmacol 1997;339:53-61.

25 Shire D, Carillon C, Kaghad M, et al. An amino-terminal variant of the central cannabinoid receptor resulting from alternative splicing. $\mathcal{F}$ Biol Chem 1995;270:3726-31.

26 Izzo AA, Mascolo N, Borrelli F, et al. Excitatory transmission to the circular muscle of the guinea pig ileum: evidence for the involvement of cannabinoid $\mathrm{CB}_{1}$ receptors. Br F Pharmacol 1998;124:1363-8.

27 Rinaldi-Carmona M, Barth F, Héaulme M, et al. SR141716A, a potent and selective antagonist of the brain cannabinoid receptor. FEBS Letters 1994; 350:240-4.

28 Coutts AA, Pertwee RG. Evidence that cannabinoid-induced inhibition of electrically evoked contractions of the myenteric plexus-longitudinal muscle preparation of guinea pig small intestine can be modulated by $\mathrm{Ca}^{2+}$ and cAMP. Can f Physiol Pharmacol 1998;76:340-6.

29 Rosell S, Agurell S. Effects of 7-hydroxy- $\Delta^{6}$-tetrahydrocannabinol and some related cannabinoids on the guinea pig isolated ileum. Acta Physiol Scand related cannabin

30 Ward SJ, Mastriani D, Casiano F, et al. Pravadoline: profile in isolated tissue preparations. F Pharmacol Exp Ther 1990;255:1230-9.

31 Pertwee RG, Browne SE, Ross TM, et al. An investigation of the involvement of GABA in certain pharmacological effects of delta-9tetrahydrocannabinol. Pharmacol Biochem Behav 1991;40:581-5.

32 Layman JM, Milton AS. Some actions of $\Delta^{1}$-tetrahydrocannabinol and cannabidiol at cholinergic junctions. Br f Pharmacol 1971;41:379-80P.

33 Paton WDM, Pertwee RG, Temple D. The general pharmacology of cannabinoids. In: Paton WDM, Crown J, eds. Cannabis and its derivatives. Oxford: Oxford University Press, 1972:50-75.

34 Yal WM, Reese LA. Cannabinoid receptor: inhibition of ACh release from myenteric plexus of small intestine. Gastroenterology 1999;116:G4791.

35 López-Redondo F, Lees GM, Pertwee RG. Effects of cannabinoid receptor ligands on electrophysiological properties of myenteric neurones of the guinea pig ileum. Br $\mathcal{F}$ Pharmacol 1997;122:330-4.

36 Fernando SR. Development of in vitro smooth muscle preparations as suitable models for elucidating the mechanism of action of cannabinoids, $\mathrm{PhD}$ Thesis. Aberdeen: University of Aberdeen, 1998.

37 Izzo AA, Mascolo N, Tonini M, et al. Modulation of peristalsis by cannabinoid $\mathrm{CB}_{1}$ ligands in the isolated guinea pig ileum. Br 7 Pharmacol noid $\mathrm{CB}_{1}$ ligands
2000;129:984-90.

38 Heinemann A, Shahbazian A, Holzer P. Cannabinoid inhibition of guinea pig intestinal peristalsis via inhibition of excitatory and activation of inhibitory neural pathways. Neuropharmacology 1999;38:1289-97.

39 Shook JE, Burks TF. Psychoactive cannabinoids reduce gastrointestinal propulsion and motility in rodents. F Pharmacol Exp Ther 1989;249:444-9.

40 Izzo AA, Mascolo N, Pinto L, et al. The role of cannabinoid receptors in intestinal motility, defaecation and diarrhoea in rats. Eur f Pharmacol 1999; 384:37-42.

41 Manara L, Landi M, Croci T, et al. Delay of gastric emptying and gastrointestinal transit by stimulation of intestinal cannabinoid $\mathrm{CB}_{1}$ receptors. FASEB $72000 ; 14: 785$.

42 Dewey WL, Kennedy JS, Howes JF. Some autonomic, gastrointestinal and metabolic effects of two constituents of marihuana. Fed Proc 1970;29:650.

43 Dewey WL, Harris LS, Kennedy JS. Some pharmacological and toxicological effects of 1-trans- $\Delta 8$ - and l-trans- $\Delta \Delta^{9}$-tetrahydrocannabinol in laboratory cal effects of l-trans- $\Delta 8$ - and l-trans- $\Delta$-tetrahydrocar
rodents. Arch Int Pharmacodyn 1972;196:133-45.

44 Anderson PF, Jackson DM, Chesher GB. Interaction of $\Delta^{9}$ tetrahydrocannabinol and cannabidiol on intestinal motility in mice. $\mathcal{f}$ Pharm Pharmacol 1974; 26:136-7.

45 Chesher GB, Dahl CJ, Everingham M, et al. The effect of cannabinoids on intestinal motility and their antinociceptive effect in mice. Br $\mathcal{F}$ Pharmacol 1973;49:588-94.

46 Anderson PF, Jackson DM, Chesher GB, et al. Tolerance to the effects of $\Delta^{9}$-tetrahydrocannabinol in mice on intestinal motility, temperature and locomotor activity. Psychopharmacologia 1975;43:31-6.

47 Jackson DM, Malor R, Chesher GB, et al. The interaction between prostaglandin $\mathrm{E}_{1}$ and $\Delta^{9}$-tetrahydrocannabinol on intestinal motility and on the abdominal constriction response in the mouse. Psychopharmacology 1976;47:187-93.

48 Calignano A, La Rana G, Makriyannis A, et al. Inhibition of intestinal motility by anandamide, an endogenous cannabinoid. Eur $f$ Pharmacol 1997;340:R7-8.

49 Colombo G, Agabio R, Lobina C, et al. Cannabinoid modulation of intestinal propulsion in mice. Eur $\mathcal{F}$ Pharmacol 1998;344:67-9.

50 Izzo AA, Mascolo N, Borrelli F, et al. Defaecation, intestinal fluid accumulation and motility in rodents: implications of cannabinoid $\mathrm{CB}_{1}$ receptors. lation and motility in rodents: implications of cannabin

Naunyn Schmiedebergs Arch Pharmacol 1999;359:65-70.
51 Izzo AA, Pinto L, Borrelli F, et al. Central and peripheral cannabinoid modulation of gastrointestinal transit in physiological states or during the diarrhoea induced by croton oil. Br f Pharmacol 2000;129:1627-32. 52 Dagirmanjian R, Boyd ES. Some pharmacological effects of two tetrahydro-
cannabinols. F Pharmacol Exp Ther 1962;135:25-33.

53 Masur J, Märtz RMW, Carlini EA. Effects of acute and chronic administration of Cannabis sativa and (-)- $\Delta^{9}$-trans-tetrahydrocannabinol on the behaviour of rats in an open-field arena. Psychopharmacologia 1971;19:38897.

54 Drew WG, Miller LL, Wikler A. Effect of $\Delta^{9}$-THC on the open-field activity of the rat. Psychopharmacologia 1972;23:289-99.

55 Costa B, Vailati S, Colleoni M. SR 141716A, a cannabinoid receptor antagonist, reverses the behavioural effects of anandamide-treated rats. Behav Pharmacol 1999;10:327-31.

56 Hanus L, Breuer A, Tchilibon S, et al. HU-308: A specific agonist for $\mathrm{CB}_{2}$, a peripheral cannabinoid receptor. Proc Natl Acad Sci USA 1999;96: $14228-33$

57 Izzo AA, Mascolo N, Capasso R, et al. Inhibitory effect of cannabinoid agonists on gastric emptying in the rat. Naunyn Schmiedebergs Arch Pharmacol 1999;360:221-3.

58 Krowicki ZK, Moerschbaecher JM, Winsauer PJ, et al. $\Delta^{9}-$ tetrahydrocannabinol inhibits gastric motility in the rat through cannabinoid $\mathrm{CB}_{1}$ receptors. Eur F Pharmacol 1999;371:187-96.

59 McCallum RW, Soykan I, Sridhar KR, et al. Delta-9-tetrahydrocannabinol delays the gastric emptying of solid food in humans: a double-blind, randomized study. Aliment Pharmacol Ther 1999;13:77-80.

60 Bateman DN. Delta-9-tetrahydrocannabinol and gastric emptying. Br f Clin Pharmacol 1983;15:749-51.

61 Coruzzi G, Adami M, Coppelli G, et al. Inhibitory effect of the cannabinoid receptor agonist WIN 55,212-2 on pentagastrin-induced gastric acid secretion in the anaesthetized rat. Naunyn Schmiedebergs Arch Pharmacol 1999;360:715-18.

62 Rivas-V JF, García R. Inhibition of histamine-stimulated gastric acid secretion by $\Delta^{9}$-tetrahydrocannabinol in rat isolated stomach. Eur $\mathcal{F}$ Pharmacol 1980;65:317-18

63 Nalin DR, Rhead J, Rennels M, et al. Cannabis, hypochlorhydria and cholera. Lancet 1978;2:859-62.

64 Sofia RD, Diamantis W, Harrison JE, et al. Evaluation of antiulcer activity of $\Delta^{9}$-tetrahydrocannabinol in the Shay rat test. Pharmacology 1978;17:173-7.

65 Coutts AA, Brewster N, Ingram T, et al. Comparison of novel cannabinoid partial agonists and SR141716A in the guinea pig small intestine. $\mathrm{Br} F$ Pharmacol 2000;129:645-52.

66 Desarnaud F, Cadas H, Piomelli D. Anandamide amidohydrolase activity in rat brain microsomes. Identification and partial characterization. $f \mathrm{Biol}$ Chem 1995;270:6030-5.

67 Katayama K, Ueda N, Kurahashi Y, et al. Distribution of anandamide amidohydrolase in rat tissues with special reference to small intestine. Biochim Biophys Acta 1997;1347:212-18.

68 Ueda N, Yamamoto S. Anandamide amidohydrolase (fatty acid amide hydrolase). Prostaglandins Other Lipid Mediators 2000;61:19-28.

69 Jerman JC, Brough SJ, Davis JB, et al. The anandamide transport inhibitor AM404 is an agonist at the rat vanilloid receptor (VR1). Br F Pharmacol 2000;129:73P.

70 Zygmunt PM, Chuang HH, Movahed P, et al. The anandamide transport inhibitor AM404 activates vanilloid receptors. Eur f Pharmacol 2000;396: 39-42.

71 Mechoulam R, Ben-Shabat S, Hanus L, et al. Identification of an endogenous 2-monoglyceride, present in canine gut, that binds to cannabinoid receptors. Biochem Pharmacol 1995;50:83-90.

72 Coutts A, Pertwee R. A comparison of cannabinoid $\mathrm{CB}_{1}$ antagonism and inverse agonism in guinea pig myenteric neurones. International Cannabinoid Research Society 2000 Symposium on the Cannabinoids. Burlington, Vermont, 2000:46.

73 Costa B, Colleoni M. SR141716A induces in rats a behavioral pattern opposite to that of CB1 receptor agonists. Acta Pharmacologica Sinica 1999; 20:1103-8.

74 Pertwee RG, Stevenson LA, Fernando SR, et al. The production of cannabinoid tolerance in preparations of mouse vas deferens and of myenteric plexus-longitudinal muscle of mouse small intestine. Br f Pharmacol 1992;107:365P.

75 Pertwee R, Fernando S, Ritchie J, et al. Preliminary validation of a novel experimental model for the study of cannabinoid tolerance. International Cannabinoid Research Society 1998 Symposium on the Cannabinoids. Burlington, Vermont, 1998:127.

76 Basilico L, Parolaro D, Colleoni M, et al. Cross-tolerance and convergent dependence between morphine and cannabimimetic agent WIN 55,212-2 in the guinea pig ileum myenteric plexus. Eur F Pharmacol 1999;376:26571 .

77 Guagnini F, Croci T, Aureggi G, et al. Tolerance to (+)-WIN55212-2 inhibitory effect and withdrawal by the cannabinoid $\mathrm{CB}_{1}$ receptor antagonist SR141716 in isolated strips of human small intestine. International Cannabinoid Research Society 2000 Symposium on the Cannabinoids. Burlington, Vermont, 2000:82.

78 Lichtman AH, Wiley JL, LaVecchia KL, et al. Effects of SR 141716A after acute or chronic cannabinoid administration in dogs. Eur $\mathcal{F}$ Pharmacol acute or chronic

79 Hine B, Friedman E, Torrelio M, et al. Morphine-dependent rats: blockade of precipitated abstinence by tetrahydrocannabinol. Science 1975;187:4435 .

80 Frederickson RCA, Hewes CR, Aiken JW. Correlation between the in vivo and an in vitro expression of opiate withdrawal precipitated by naloxone: their antagonism by $l-(-)-\Delta^{9}$-tetrahydrocannabinol. F Pharmacol Exp Ther 1976;199:375-84

81 Morrone LA, Romanelli L, Mazzanti G, et al. Hashish antagonism on the in vitro development of withdrawal contracture. Pharmacol Res 1993;27(suppl 1):63-4.

82 Mechoulam R. The pharmacohistory of Cannabis sativa. In: Mechoulam R, ed. Cannabinoids as therapeutic agents. Boca Raton: CRC Press Inc., 1986:1-19.

83 Pertwee RG. Cannabinoid receptors and pain. Prog Neurobiol (in press). 